small amateur who is induced to experiment will surely find himself in trouble.

In the chapter "Orchid Names," the author follows the popular lead by finding fault with the existing orchid nomenclature, and with the inevitable result that he is unable even to hint at a better method than that for which we have to thank a long line of patient and clever men who have been working on the subject in all ages since the classification of plants began. It should be remembered that the question is not as to whether the name is good or bad Latin or Greek, expressive or not expressive, but that it is intended as a means of identifying the plant in every civilised quarter of the globe, an end which no system of popular names could accomplish, but which has worked under the present system of scientific names in a marvellously satisfactory manner. To apply it to his own case. Deprived of the scientific names he finds fault with, Mr. Boyle's book would have been impossible in its present useful form.

Orchid culture cannot be reduced to an exact science. Each operator has to adapt his methods to his convenience, but in order to know how to meet his difficulties and to overcome them, Mr. Boyle's book will be found invaluable. In some cases the prices at which the plants may be obtained are also given.

\section{THE ROYAL VISIT TO THE UNIVERSITY OF} WALES.

THE installation of the Prince of Wales as the second Royal Chancellor of the University of Wales is associated with an important epoch in the develop. ment of university education in North Wales. When the University College of North Wales was founded in I 884 , it would have been difficult to find a more ideal situation for a centre of university education than the Penrhyn Arms Hotel at Bangor, which possessed ample accommodation for existing requirements. But eighteen years ago, Hertz's realisations of Maxivell's theory of electric oscillations, culminating in wireless telegraphy, did not exist ; the existence of Röntgen and other rays had not been anticipated; no argon was known to exist in our atmosphere, no helium in our earth ; the liquefaction of the more permanent gases was regarded as a mere classical experiment, impossible on a large scale; even in mathematics, the fertile theory of groups was almost untrodden ground. Taking also into account the increase in the number of students in the eighteen years from 55 to 320 , it is small wonder that new buildings with more modern equipments have now become indispensable for the further progress of the College. These needs bid fair to be soon met by the recent generous gift on the part of the City of Bangor of a new plot of ground $10^{\circ} 6$ acres in extent, about 6.6 acres of which are available for building purposes, on a site which, in the opinion expressed by Principal Reichel, "any university College in the kingdom might well envy." This gift represents, for the City of Bangor, the equivalent of a gift of one million pounds from the citizens of a wealthy town comparable with Liverpool.

The smallness of the population of Bangor and the absence of the large wealth-producing industries of our midland towns are a sufficient guarantee that the new College need never fear the disturbing influences of electric trams and the smoke and din of factories which have afforded such an obstacle to scientific research in wealthy and thickly populated manufacturing centres.

The University congregation was held, not at Bangor, but at Carnarvon, where the large pavilion had been transformed into a senate house. The lavish display of bunting at Carnarvon and subsequently at Bangor; the gowns and hoods of graduates, extending over the whole range of colours from violet to red, and the No. I698, voL. 66 j presence of large contingents of students from Aberystwyth, Bangor and Cardiff, including a considerable proportion of "sweet girl undergraduates" in caps and gowns, all contributed to the festivity of the scene. Even the mountain ranges of Snowdonia were clad in white hoods of snow rarely seen in May. The actual installation ceremony having been completed by the presentation of the key of the University seal and a copy of the statutes to the Prince as Chancellor, addresses were read by Dr. Isambard Owen and Principal Roberts on behalf of the University court and senate, and addresses were also presented or read on behalf of several other bodies, including the guild of graduates. The Prince in reply, after referring to the work done by teachers and students of the Welsh University, laid special stress on the encouragement given to post-graduate and scientific work, and the fact that it is by the work done in after life by its graduates that the reputation of a university is really made. The Chancellor then admitted the Princess of Wales to an honorary degree in music and proceeded to the conferment of honorary degrees, in which science was represented by the Farl of Rosse, the recipients being presented by Vice-Chancellor Roberts, of Aberystwyth. The intervals in the proceedings were filled by part songs sung by a well-trained choir, and at the conclusion the problem of transporting the guests to Bangor was solved with remarkable success. Here luncheon was laid for six hundred and filty in a marquee pitched close to the new site, under the chairmanship of Lord Kenyon. In his speech, the Prince of Wales once more struck a chord which he had already sounded at the National Physical Laboratory in referring to his recent tour and his experience of the work done in universities across the seas in bringing intellectual ability to the front and rendering it available for the public service. This line of thought was ably echoed by Principal Reichel in his remarks that "The idea, which at one time was not un. common, that intellectual training is unfavourable to action is now happily becoming discredited at home ; on the Continent it has long ago perished.... The function of provincial university colleges is, in short, to train up a more vigorous and efficient race, fitted to meet the heavy demands which the course of world events is making on the inhabitants of these islands, a race of more efficient thinkers, of more efficient workers, and if the necessity should arise, of more efficient fighters." Principal Reichel further announced the receipt of an offer of twelve scholarships of $30 /$. for three years from Sir Alfred L. Jones, of Liverpool. It was also announced that the town of Cardiff, like Bangor, has presented its University College with a new site.

The next item was the visit of the Prince and Princess to the present College, where a guard of honour was formed by the College volunteer corps. Interest naturally centred round the museums and laboratories. The College possesses a very fair zoological museum, and it is proposed to establish in connection with the same department a marine station where problems connected with the fisheries of the North Wales coast can be studied systematically. Already efforts have been made to arouse interest in the fishing industry by popular lectures. Most of the work of the College in agriculture has been hitherto carried on at a farm right away near Llangefni, but the College is now indebted to Colonel Platt for an experimental farm in a much more accessible situation near Llanfairfechan. Of other recent developments on the science side, we note the Drapers' Company's temporary endowment of a school of electrical engineering, a school which is bound to develop when a university training is, as it should be, insisted on in this country as an indispensable qualification for every electric engineer. The organisation of a department of mining is also, thanks to the support of local bodies, approaching completion. A recent gift from $\mathrm{Mr}$. George Rae for the purpose of 
providing teaching in banking and finance affords evidence that the commercial side of modern university education has not been overlooked, and a further gift from the trustees of the late Sir Henry Tate has been announced.

The last item in the Royal visit to Bangor was the visit of the Princess of Wales to the University Hall, where an enthusiastic reception from the women students, assembled in cap and gown under Miss Fowle, was awaiting the Royal party.

If there is one function on which the University of Wales, in common with other universities, will have to lay cver-increasing stress, that function is the dissemination in the less accessible parts of the Principality of those internationalising influences which are now bringing all parts of the civilised globe into closer touch with each other. The deliberations of English-. French- and German-speaking science workers are daily beconing more and more international in character, and this influence is spreading gradually down the educational ladder. The late Mr. Cecil Rhodes's scheme for fostering the international spirit in Oxford is still in our minds, and it may be confidently hoped that modern and wellequipped University College buildings both in North and South Wales will do much to promote that educational influence which may so well be summed up in the word "internationalisation."

G. H. BRYAN.

\section{THE IRON AND STEEL INSTITUTE.}

THE annual meeting of the Iron and Steel Institute was held on May 7 and 8 , and a short report of the proceedings is subjoined. At the annual dinner of the Institute, on Wednesday of last week, Mr. AmoldForster made a few remarks upon the duties of the State towards science, and the necessity for the intro. duction of scientific organisation and method in all departments and works of a progressive character. We give his speech as reported by the Times:-

Mr. Arnold-Forster said that however little he might contribute to the (rovernment in any other matter, he did contribute in full measure great respect, great admiration and great reverence for science and scientific organisation. By scientific organisalion he meant the application to the ordinary work of everyday life, the work which had been thought out and coordinated by sludients of science. In liis country we were probably behind almost every other great country in the recognition of the great truth that science had a lesson for everyone in producing economy and efficiency by the application of a scientific method. There was a time when the duty of the State to take its part in ordering the work of the nation was more clearly recognised and acted upon than it was now. The enormous attention which was given to regulating our coinage and $(0)$ giving us a system of weights and measures formed a considerable part of the earlier economic histury of this country. But when we had accomplished those one or two rudimentary duties, the State appeared to think that nothing more could be accomplished or was to be expected from it as the administrator and as the instrument to apply in the teaching of science. But the time had gone by when we could afford any longer to fail to recognise the direct duty of the State to the country in the ma' ter of organising on some scientific principle many of the must. important departments of our scientific life. (iovernments were now so enlightened that they could interfere in scientific matters with certainiy of producing the results which they desired. It should be insisted upon that in every department which came within the purview of the Government there should be scientific corrdination and organisation. He would not speak of weights and measures-though there, indeed, a wise Government might step in-but there was the kindred branch of scientific application about which he would say a wordnamely, standiardisation and the uniformity of tests. In that regard we were behind the Continental nations. He had been studying the publications of the great Con. tinental nations for the coordination of tests of materials

No. I 698 , vOL. 66 ] and the institution of standard dimensions, and the conviction had been forced upon him that we had already allowed opportunities of cooperation to go by which we ought to have seized. He was glad that at the eleventh hour the Iron and Steel Institute, the Institution of Civil Engineers and the Institute of Naval Architects had taken up the work. He wished every success to it. The French Government were standardising their railway material, but nothing corresponding to that existed in the records of our Governmental arrangements. In inspecting a steel works recently he found that in the matter of tensile strength for steel there w'as one test for the Admiralty, another for the War Office, another for the Buard of Trade, another for one set of railway companies, and another for another set (the Boardi of Trade recognising neither), another for the ligyptian (iovernment, another for the Indian Government, and another for the whole of the Continent of Furope. That was absolutely crazy. It was like measuring pints by fourteen different kinds of pint pots. They were all sinners in that respect -all the departments-because it ought not to be allowed. He urged that scientific societies should forward the work of standardisation as forcibly as possible. Already in the Admiralty great strides were being made, thanks to Sir William White, and already they had succeeded 10 some extent in the standardisation of electrical appliances. They had also standardised in the whole of the gunnery branch, and were now endeavouring to do so to a much larger extent in the whole of the fittings of the ships. When the Iron and Steel Institute and kindred associations had made up their minds as to what was the true method of standardisation they should go boldly to the Government and ask them to undertake that within a definite time all Guvernment specifications should be within the terms of that standardisation. He was not unaware that there was a danger in standardisation, that one must not stereotype too closely, and must not interfere with improvement by solidifying all patterns; and therefore he trusted that they would insist upon it that the Government should be the cooperators in the work in which the Iron and Steel Institute and kindred societies must be the kindred spirits. In conclusion, he said that we had been too modest in this country of advancing the claims of science. What was done for applied science in every other civilised country should make us ashamed of the pittances doled out in England, which were supplemented to the extent of 99 per cent. by private charity, for the purpose of performing those elementary duties of coordinating the scientific part of this country's life. He believed that if the scientific associations took a high line in the matter the country would support them right through.

Other speakers at the dinner were Sir Alfred Hickman, Admiral Sir N. Bowden-Smith, Sir Bernhard Samuelson, Lord Raglan, Lord Blythswood, Sir Christopher Furness, Sir W. C. Roberts-Austen, General Sir John Maurice, Sir Norman Lockyer and the president.

At the annual meeting of the Institute the chair was occupied by the president, Mr. W. Whitwell. The Bessemer gold medal was presented to $\mathrm{His}$ Excellency F. A. Krupp, of Essen. The Andrew Carnegie medal was awarded to 1)r. J. A. Mathews for the research described in his report; and Andrew Carnegie research scholarships, each of $100 l$, were awarded to Messrs. O. Boudouard (Paris), W. Campbell (New York), A. Campion (Coopers Hill), P. Longmuir (Manchester), E. Schott (Berlin) and F. H. Wigham (Wakefield). The following are the chief points of the papers read :-

In the first paper, Mr. J. H. Darby embodied the results of experiments made with the object of improving the quality of coke by compressing the fuel before coking. The net gain in production of coke per ovell was found 10 be between 10 and 12 per cent. in favour of the compressed charge.

Mr. J. Thiry read a paper on the recovery of by.products in coke-naking. He gave some striking figures showing the profit and economy derived from this meihod of coke manufacture, and described the most recent form of the Otto-Hilyenstock coke oven. These two papers gave rise to an interesting discussion, in which Sir Lowthian Bell, Sir Bernhard Samuelson, Dr. Ludwig Mond and other members took part. 